\title{
"Impact of Covid-19 on the budget security of the national economy: a forecast for Ukraine"
}

\begin{tabular}{|c|c|}
\hline \multirow{5}{*}{ AUTHORS } & Victoria Strilets (1) https://orcid.org/0000-0001-9729-9210 \\
\hline & R https://publons.com/researcher/1883996/victoria-yu-strilets/ \\
\hline & Olha Prokopenko (D http://orcid.org/0000-0003-1362-478X \\
\hline & R https://publons.com/researcher/1387676/olha-prokopenko/ \\
\hline & Volodymyr Orlov (D https://orcid.org/0000-0002-2052-6654 \\
\hline ARTICLE INFO & $\begin{array}{l}\text { Victoria Strilets, Olha Prokopenko and Volodymyr Orlov (2020). Impact of Covid- } \\
19 \text { on the budget security of the national economy: a forecast for Ukraine. Public } \\
\text { and Municipal Finance, } 9(1), 25-33 \text {. doi:10.21511/pmf.09(1).2020.03 }\end{array}$ \\
\hline DOI & http://dx.doi.org/10.21511/pmf.09(1).2020.03 \\
\hline RELEASED ON & Monday, 09 November 2020 \\
\hline RECEIVED ON & Saturday, 15 August 2020 \\
\hline ACCEPTED ON & Monday, 02 November 2020 \\
\hline & $(\mathrm{ccc}) \mathrm{EY}$ \\
\hline LICENSE & $\begin{array}{l}\text { This work is licensed under a Creative Commons Attribution } 4.0 \text { International } \\
\text { License }\end{array}$ \\
\hline JOURNAL & "Public and Municipal Finance" \\
\hline ISSN PRINT & $2222-1867$ \\
\hline ISSN ONLINE & $2222-1875$ \\
\hline PUBLISHER & LLC "Consulting Publishing Company "Business Perspectives" \\
\hline FOUNDER & LLC "Consulting Publishing Company "Business Perspectives" \\
\hline $0^{0}$ & 三E: \\
\hline NUMBER OF REFERENCES & NUMBER OF FIGURES \\
\hline 24 & 3 \\
\hline
\end{tabular}

(C) The author(s) 2022. This publication is an open access article. 


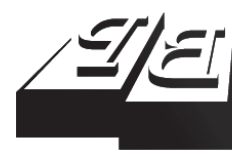

BUSINESS PERSPECTIVES

(O)

LLC "CPC "Business Perspectives"

Hryhorii Skovoroda lane, 10,

Sumy, 40022, Ukraine

www.businessperspectives.org

Received on: $15^{\text {th }}$ of August, 2020 Accepted on: $2^{\text {nd }}$ of November, 2020

Published on: $9^{\text {th }}$ of November, 2020

() Victoria Strilets, Olha Prokopenko, Volodymyr Orlov, 2020

Victoria Strilets, Ph.D., Higher Educational Institution of Ukoopspilka,

Ukraine Poltava University of Economics and Trade, Ukraine. (Corresponding author)

Olha Prokopenko, Professor, Business Administration Department, Tallinn University of Technology, Estonia.

Volodymyr Orlov, Head of Department, Asset Recovery and Management Agency, Ukraine.

\section{IMPACT OF COVID-19 ON THE BUDGET SECURITY OF THE NATIONAL ECONOMY: A FORECAST FOR UKRAINE}

\begin{abstract}
Nowadays, it is necessary to consider the impact of the COVID-19 pandemic on the state of the national economy, in particular on the budget system. This paper examines the essence of budget security and identifies the key threats to budget security in the current context. The methodological aspects of calculating Ukraine's budget security key indicators (their list, criteria for the use of weighting factors, range of characteristic values of budget security levels) are investigated and their state in 2015-2019 is assessed. The influence of quarantine measures on the level of budget security in Ukraine is determined. Analysis of the current state of budget security and development prospects of Ukraine, determined by the Ministry for Development of Economy, Trade and Agriculture of Ukraine, the International Monetary Fund and the World Bank Group, made it possible to predict Ukraine's budget security indicators for 2020-2021 and define prospects for changing budget security of Ukraine until 2024. Based on the results of forecasting, the need was identified for planning and implementing urgent anti-crisis measures in the field of managing the country's budget security, as well as ensuring the consistency of the norms of budget and tax legislation in integration with effective measures to support the socio-economic environment of Ukraine.
\end{abstract}

\section{Keywords budget, security, budget policy indicators, budgetary forecasting, risks}

\section{JEL Classification $\quad \mathrm{H} 12, \mathrm{H} 61$}

\section{INTRODUCTION}

The budgetary component of Ukraine's economic security is shaped under the influence of many factors transforming the business environment, the changes in vectors and development strategies, as well as relationships in society. There is a significant list of threats to budget security (a high level of the government budget deficit, a large amount of public debt, an increase in the state's social obligations, inflation and devaluation fluctuations, etc.). However, the problems facing the world due to the Covid-19 pandemic have had a significant impact on the economies of the countries, shaking the stability of all components of economic security, especially in the area of the budget system. The crisis caused by the pandemic in Ukraine has become systemic (a permanent decline in industrial production, a decline in economic activity, a gradual decline in exports and trade imbalances, and, as a consequence, a reduction in consolidated budget revenues and an increase in the budget deficit). Therefore, ensuring budget security is one of the priority issues to be addressed, since it determines the increase in the standard of living of the population, the strengthening of defense capabilities, as well as social and cultural development. 


\section{LITERATURE REVIEW}

In recent years, budget security has become the focus of many Ukrainian scientists. Thus, Makarchuk et al. (2017) argue that budget security is an important factor in the state's socio-economic development, an indicator and criterion for the effectiveness of its budget policy and organization of the budget process. Zveruk and Bilyk (2017) note that budget security should ensure the solvency and financial stability of public finances, which will allow public authorities to perform their functions as effectively as possible. According to Sytnyk and Subytska (2018), budget security should ensure the financial sustainability and solvency of public finances, which will allow state bodies to effectively perform their functions.

According to the normative definition by the Ministry for Development of Economy, Trade and Agriculture of Ukraine (2013), budget security is a state of a country's solvency with reference to the balance of revenues and expenditures of the state and local budgets and the efficient use of budget funds. From an economic point of view, budget security expresses the ability of the state to perform its functions and tasks through the budget, as well as to meet the needs of taxpayers and recipients of budget funds, taking into account individual, corporate and public interests (Kyshakevych, 2012).

According to Frolov (2015), budget security reflects the special state of the country's solvency, which ensures the balancing of revenues and expenditures of state and local budgets and the efficient use of financial resources of the budget system in the process of performing state and local government functions (by maintaining the financial stability (sustainability) of the budget system to the impact of threats). The inseparability of threats and security leads to the formation of author's polemics in understanding their essence. In this study, threats are understood as a set of negative prerequisites and factors that impede the full realization of budgetary interests and cause a complete or partial violation or destruction of the budget system and budget process (Zveruk, 2017). The main threats to budget security include: a significant level of public debt and high costs for its repayment; uneven socio-economic development of the country's regions; lack of funds to finance the development of priority sectors of the economy; social differentiation of the population of regions, un- derdeveloped social infrastructure (Sytnyk, 2018); the level of budget deficit, the predominance of external and internal borrowing in the financing the government budget, ineffective tax system, understatement of the tax base by economic entities and tax evasion; ineffective system of control over the spending of budget funds (Pedchenko, 2014); giving priority to a certain budget classification, the degree of perfection of the accounting system of budget execution and cost estimates of budgetary institutions; timeliness of decisions on budget and tax regulation; the nature of the cash execution of the budget; the degree of coordination of financial and economic interests of different social groups (Makarchuk, 2017); high energy intensity of the economy and the irreversibility of the need to use energy efficient technologies and non-traditional energy sources, deterioration of the demographic calendar, reduction/loss of labor potential in the context of an unreformed pension system (NISS, 2017). According to Chugunov et al. (2020), crisis processes in the national economy require a timely and effective assessment of the impact of exogenous and endogenous factors on the state's budget policy. As Jarkinbayev and Kosherbayeva (2018) rightly point out, in the context of global economic instability, there is a growing need for accurate forecasts of macroeconomic indicators to make informed decisions about the socio-economic policy of the state. At the same time, budget security is one of the main factors determining overall competitiveness. In particular, the assessment of public finances, on the one hand, shows the impact on the country's international competitiveness, and, on the other hand, allows you to determine the strategic direction of competitiveness (Zakharchenko, 2016). The formation of fiscal capacity in different countries is influenced by different environmental factors, which causes differences in the construction of the budget system and requires the adaptation of methodological tools for its assessment (Pedchenko, 2014). Lyulyov (2017) points to the need to introduce additional economic indicators aimed at considering the cyclical nature of the country's development and the economic consequences of global crises, including epidemiological ones.

Given the current situation in Ukraine and the world against the backdrop of the COVID-19 pandemic, it is necessary to update the budget security calculations, taking into account the newly creat- 
Table 1. List of indicators for calculating the integrated index of the country's budget security and their weighing coefficients

Source: Ministry for Development of Economy, Trade and Agriculture of Ukraine (2013).

\begin{tabular}{l|c|c}
\hline \multicolumn{1}{c}{ Debt security indicator } & $\begin{array}{c}\text { The procedure for calculating the } \\
\text { indicator }\end{array}$ & $\begin{array}{c}\text { Weighting coefficients for calculating } \\
\text { economic security sub-indices }\end{array}$ \\
\hline $\begin{array}{l}\text { The ratio of the government budget } \\
\text { deficit/surplus to GDP, } \%\end{array}$ & $\begin{array}{c}\text { Government budget deficit, UAH mln/GDP, UAH } \\
\mathrm{mln} \times 100\end{array}$ & 0.2671 \\
\hdashline $\begin{array}{l}\text { Deficit/surplus of budgetary and } \\
\text { extra-budgetary funds of the general } \\
\text { government sector, \% of GDP }\end{array}$ & $\begin{array}{c}\text { (General government deficit, UAH mln - } \\
\text { Consolidated budget deficit, UAH mln) / GDP x }\end{array}$ & 100
\end{tabular}

ed threats and post-pandemic scenarios of economic development.

\section{METHODOLOGY}

The methodology for calculating the budget security integrated index as a component of Ukraine's economic security is reflected in the order of the Ministry for Development of Economy, Trade and Agriculture of Ukraine On the Approval of Methodological Recommendations for Calculating the Level of Economic Security of

Indicator 1

The ratio of the government budget deficit/surplus to GDP, \%

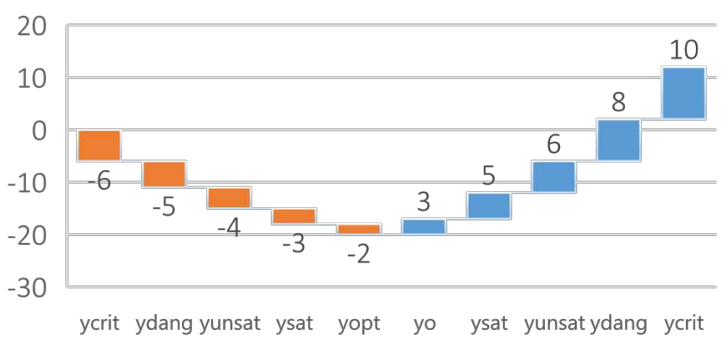

Indicator 3

The level of redistribution of GDP through the consolidated budget, \%

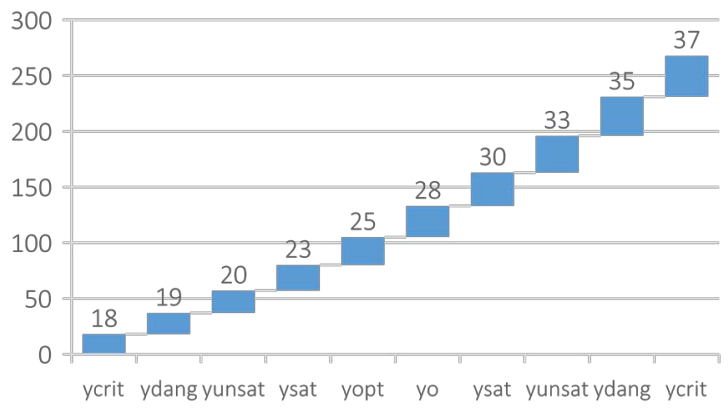

Ukraine (Ministry for Development of Economy, Trade and Agriculture of Ukraine, 2013). According to the methodology, there are several key indicators for assessing the country's budget security (see Table 1).

For each indicator, an appropriate range of characteristic values of budget security levels is established. This allows classifying them into an optimal level $\left(\mathrm{y}_{\mathrm{opt}}\right)$, a satisfactory level $\left(\mathrm{y}_{\text {sat }}\right)$, an unsatisfactory level ( $\left.\mathrm{y}_{\text {unsat }}\right)$, a dangerous level $\left(\mathrm{y}_{\mathrm{dang}}\right)$, a critical level $\left(\mathrm{y}_{\text {crit }}\right)$, and an absolutely dangerous level $\left(\mathrm{y}_{\mathrm{o}}\right)$ (see Figure 1).

Indicator 2

Deficit/surplus of budgetary and extra-budgetary funds of the general government sector, \% of GDP

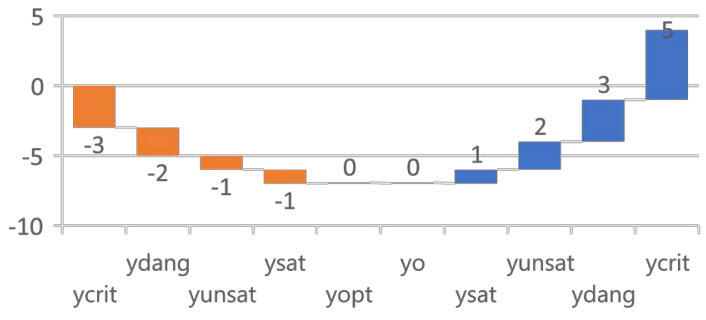

Indicator 4

The ratio of total payments for servicing and repayment of public debt to government budget revenues, $\%$

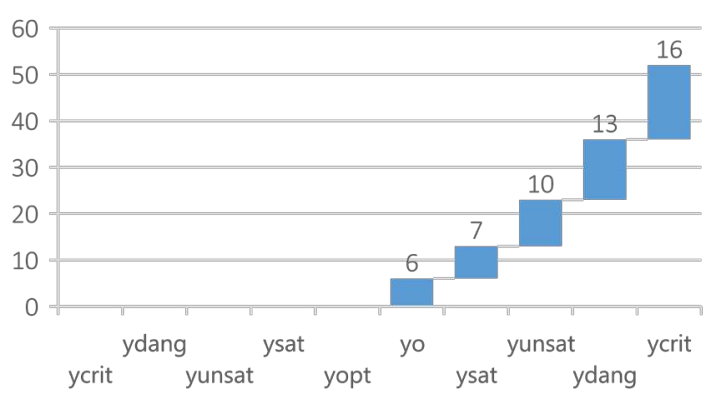

Figure 1. Range of eigenvalues of budget security levels 


\section{RESEARCH RESULTS}

Analyzing the components of budget security for 2015-2019 (see Table 2), one can observe the dangerous situation with its main indicators, which are in the risk zone. The impact of threats on the budget security of the state is confirmed by the presence of indicators in the danger zone (the ratio of total payments for servicing and repayment of public debt to government budget revenues). There is a rapid increase in the volume of budget deficit, inflationary processes, the devaluation of the hryvnia, limited access to cheap financial resources in the financial markets, which contributes to an increase in the cost of servicing public debt. According to the Stability and Growth Pact, the budget deficit should not exceed 3\% of GDP, and public debt should not exceed $60 \%$ of GDP (EC, 2011). At the same time, each country determines its critical indicators to maintain a safe level of budget deficit and public debt (Chugunov, 2019). In particular, according to the main directions of budgetary policy for 2019-2021 in Ukraine, the state budget deficit is projected at $2.2 \%$ of GDP, the maximum amount of public debt - no more than 56\% of GDP (Cabinet of Ministers of Ukraine, 2018).

Negative trends are also observed in the growing deficit of budgetary and extra-budgetary funds of the general government sector. Thus, from the unsatisfactory level in 2015, the indicator gradually moved to a dangerous level, and dynamics of approaching the critical zone is observed.

The change in the ratio of total payments for servicing and repayment of public debt to government budget revenues should be assessed positively from $93.72 \%$ at the beginning of the analyzed period to $46.5 \%$ in 2019 . However, one should agree with the assertion of Hotlib (2019) that the excess of the deficit in GDP growth rates when it is financed from borrowings, and not from domestic sources, predicts more than one year of staying the size of Ukraine's public debt beyond the safety line.

In 2020, the spread of the COVID-19 pandemic was the most significant factor in the country's economic development. The influence of this factor was so significant that it changed almost all areas of the socio-economic environment of Ukraine. The decline in economic activity after the introduction of quarantine contributed significantly to the acceleration of the decline in industrial production, which amounted to $7.7 \%$ in January-July 2020 compared to the corresponding period in 2019. In the mining industry, the decline was by $5.5 \%$, in the processing industry - by $9.2 \%$, in the supply of electricity, gas, steam and conditioned air - by $5.3 \%$. Mechanical engineering and metallurgy experienced a deep decline $--22.1 \%$ and $-13.6 \%$, respectively (NISS, 2020). The decline in domestic and foreign demand for investment products (industrial equipment, vehicles, etc.) and products for end consumers has become a determining factor in the deepening of the crisis trends.

Among the key measures taken to stop the pandemic and which had a direct impact on the country's economic security indicators, the following should be noted:

introduction of quarantine zones;

- cancellation of public events (sports, entertainment, religious gatherings, etc.);

- closure of educational and cultural and entertainment institutions;

- setting limits on departure/entry to countries and movement within countries;

Table 2. Ukraine's budget security indicators in 2015-2019

\begin{tabular}{|c|c|c|c|c|c|}
\hline Budget security indicator & 2015 & 2016 & 2017 & 2018 & 2019 \\
\hline The ratio of government budget deficit/surplus to GDP, \% & -2.28 & -2.94 & -1.6 & -1.7 & -2 \\
\hline $\begin{array}{l}\text { Deficit/surplus of budgetary and extra-budgetary funds of the } \\
\text { general government sector, \% of GDP }\end{array}$ & -1.61 & -3.59 & -1.88 & -2.15 & -2.05 \\
\hline $\begin{array}{l}\text { The level of redistribution of GDP through the consolidated } \\
\text { budget, } \%\end{array}$ & 32.94 & 32.84 & 34.09 & 33.3 & 32.5 \\
\hline $\begin{array}{l}\text { The ratio of total payments for servicing and repayment of } \\
\text { public debt to government budget revenues, } \%\end{array}$ & 93.72 & 33.62 & 59.75 & 37.7 & 46.5 \\
\hline
\end{tabular}


Table 3. Changes in the main predictors of Ukraine's budget security according to state and world economic organizations in 2020-2021

\begin{tabular}{|c|c|c|c|c|c|c|}
\hline \multirow[t]{2}{*}{ Indicator } & \multicolumn{2}{|c|}{$\begin{array}{c}\text { Forecast of the Ministry for Development } \\
\text { of Economy, Trade and Agriculture of } \\
\text { Ukraine }\end{array}$} & \multicolumn{2}{|c|}{ IMF forecast } & \multicolumn{2}{|c|}{$\begin{array}{l}\text { World Bank } \\
\text { forecast }\end{array}$} \\
\hline & 2020 & 2021 & 2020 & 2021 & 2020 & 2021 \\
\hline GDP nominal, UAH billion & 3,964 & $4,391.4$ & 3,908 & 4,277 & $x$ & $x$ \\
\hline$\%$ of actual change & -6 & 3.2 & -8.2 & 1.1 & -3.5 & 3 \\
\hline $\begin{array}{l}\text { Consolidated budget revenues, } \\
\text { UAH billion }\end{array}$ & $1,227.3$ & 1,299.6 & $x$ & $x$ & $x$ & $x$ \\
\hline Share of GDP, \% & 31 & 29.6 & $x$ & $x$ & $x$ & $x$ \\
\hline Public debt, UAH billion & $2,212.9$ & 2,425 & $x$ & $x$ & $x$ & $x$ \\
\hline Share of GDP, \% & 55.8 & 55.2 & $x$ & $x$ & $x$ & $x$ \\
\hline Budget deficit, UAH billion & 217.7 & 149.5 & $x$ & $x$ & $x$ & $x$ \\
\hline Share of GDP, \% & 5.5 & 3.4 & $x$ & $x$ & $x$ & $x$ \\
\hline
\end{tabular}

- strengthening the role of public administration in emergency situations;

- $\quad$ setting limits on employment;

- $\quad$ restricted import-export operations;

- introduction of new remote forms of work and education, etc. (Ministry for Development of Economy, Trade and Agriculture of Ukraine, 2020).

According to international organizations, Ukraine will show a deeper recession than the world economy, which will amount to 6\% in 2020 (according to the previous consensus forecast, the decline was $4.2 \%$ ).

The measures introduced caused a chain reaction from a decrease in trade to a decrease in wages, from suppression of international tourism, an increase in the risk of bankruptcy of small businesses to a slowdown in the Ukrainian economy as a whole. The result is a reduction in GDP, a widening gap between budget expenditures and revenues, and a deepening of the debt crisis. In particular, according to the Ministry for Development of Economy, Trade and Agriculture of Ukraine, the drop in GDP by the second quarter of 2019 was $11 \%$ (against the forecast of 14\%) (Ministry for Development of Economy, Trade and Agriculture of Ukraine, 2020).

Scenarios of changes in the main predictors of budget security according to state and world economic organizations (see Table 3) show that Ukraine's GDP will decrease by at least half, and according to the most pessimistic forecast of the IMF, it will decrease to $8.2 \%$. Besides, World Bank experts predict rise in inflation in Ukraine this year to $8.9 \%$ with a state budget deficit of $4.9 \%$ of GDP, a current account deficit of $2.7 \%$ of GDP, and an increase in public debt to $59 \%$ of GDP, while in 2019, this figure was 51\% of GDP (Kulytskyi, 2020). However, according to forecasts, 2021 will see some improvements both in GDP growth rates and in other indicators of Ukraine's budget security. It can be assumed that the nature of the recovery will depend on the existing quarantine measures in Ukraine, as well as enhanced measures in terms of "adaptive quarantine", which will have a negative impact on the country's economy, as a result of which the recovery will be slow.

Given the existing changes in the forecast, forecasting of Ukraine's budget security indicators for 2020-2021 is made (Figure 2).

The obtained forecast values make it possible to determine the prospects for changes in the level of the integrated indicator of Ukraine's budget security (see Figure 3). The analysis shows that budget security is currently at a critical level and without adjusting the fiscal policy, it will not be able to achieve positive upward trends. One of the priority tasks of budget security is to achieve a stable condition of public finances; according to Kudriashov (2012), this is a state that does not lead to an extreme increase in the fiscal burden and 
The ratio of the government budget deficit/surplus to GDP, \%

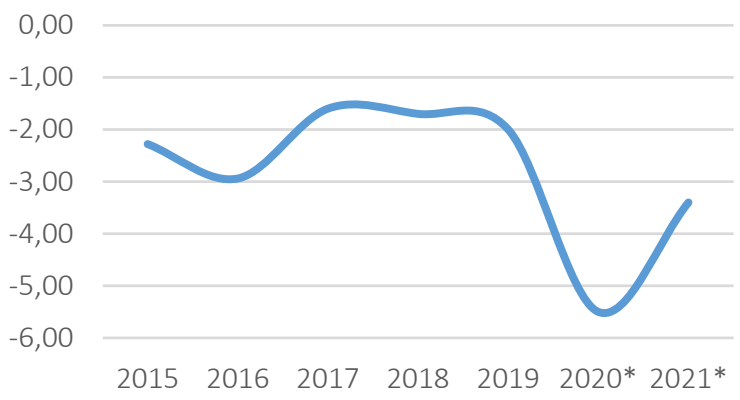

The level of GDP redistribution through the consolidated budget, \%

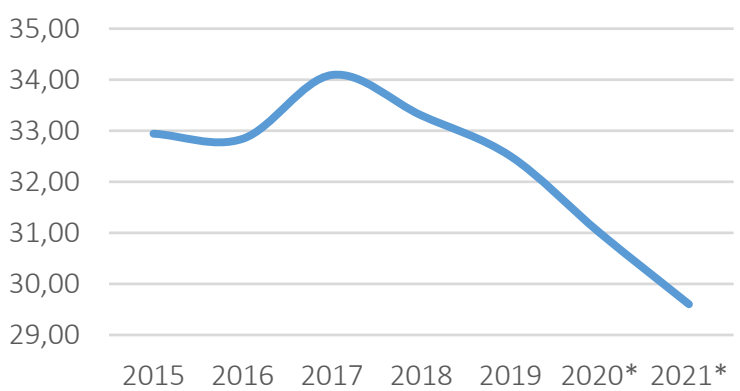

Deficit/surplus of budgetary and extrabudgetary funds of the general government sector, \% of GDP

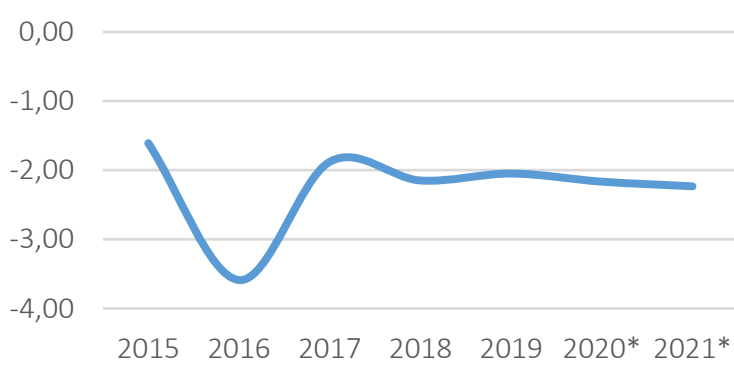

The ratio of total payments for servicing and repayment of public debt to government budget revenues, \%

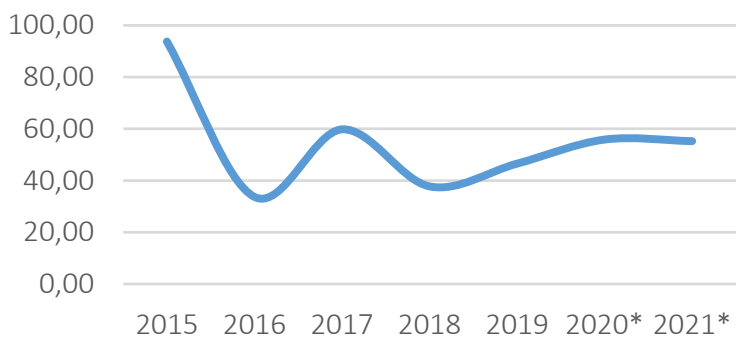

Figure 2. Actual (2015-2019) and forecast (2020-2021) values of Ukraine's budget security indicators

the total amount of public debt, the accumulation of liabilities and deterioration of their structure (Kudriashov, 2012).

It should be noted that the speed of economic recovery will depend on:

- duration and depth of internal quarantine measures;

- external environment;

- $\quad$ support through fiscal and monetary policy;

- possible future changes in consumer and investor behavior.

The state plays a critical role in overcoming the consequences of the pandemic. When pursuing fiscal policy, the state should determine the shortterm priority of planning and implementing urgent anti-crisis measures, funds transfer instruments, contingency reserves, etc. To do this, it is necessary to develop a set of measures, the im- plementation of which should be entrusted to the Ministry of Finance of Ukraine, the Ministry for Development of Economy, Trade and Agriculture of Ukraine, the Ministry of Infrastructure of Ukraine, the Ministry for Communities and Territories Development, the Ministry of Digital Transformation of Ukraine, state and local authorities and local self-government bodies. Key measures include:

- improvement of tax administration mechanisms and the formation of a unified database to ensure a complete and transparent accounting system, which will ensure effective fiscal control and increase budget revenues;

- ensuring the smooth operation of SMEs, creating opportunities to overcome the post-pandemic crisis without introducing additional restrictions and prohibitions;

- introduction of a temporary moratorium on increasing tariffs for services (transport, logistics, housing and communal services, etc.); 


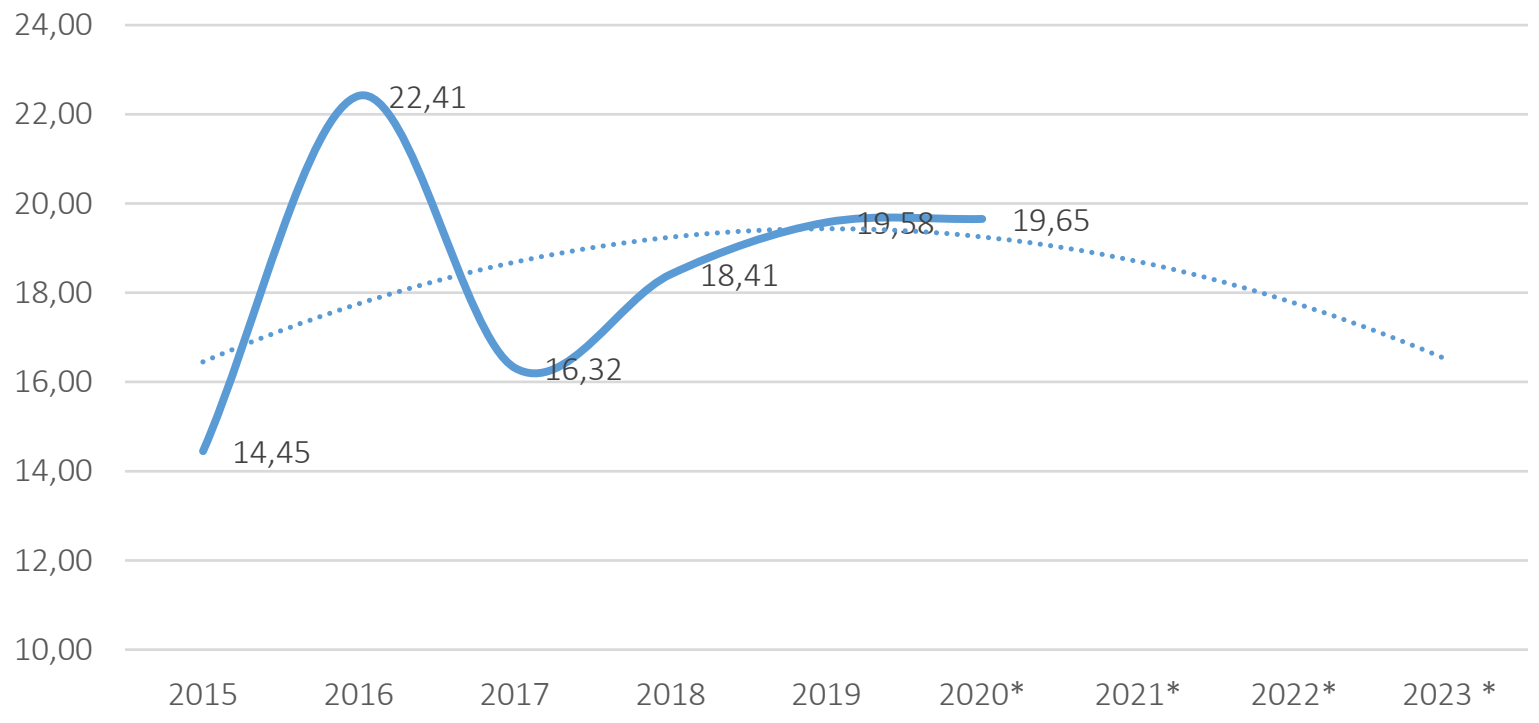

Figure 3. Dynamics of the integrated indicator of Ukraine's budget security in 2015-2023

- completion of the process of electronic verification of social expenditures monitoring and transition to the provision of targeted social benefits;

- introduction of a number of tax benefits and preferential customs rates for raw materials to intensify the production activities of business entities;

- popularization of the program of simplified lending to business entities at low interest rates;

- financing of existing state infrastructure projects and projects to support entrepreneurship in Ukraine.

Given the forecasts of macroeconomic development of the EU countries developed by the European Commission (EC, 2020), it is advisable to use the Polish experience in achieving economic stability and maintaining budget security. Thus, according to the forecast, the negative impact of Covid-19 on the national economy of Poland is the lowest $(-4.6 \%)$ among the indicators in the $\mathrm{EU}$ countries (the average drop in GDP is projected at $-8.7 \%)$. Among the main factors that contributed to this success, the following should be highlighted for adaptation in Ukraine:

- "diversification" of the economy. There are no priority sectors in the national economy of Poland, each branch of economic activity makes an equally significant contribution to the formation of the country's GDP;

- low dependence on exports: Poland is a country with a sufficient domestic market. Considering that the Security Strategy identifies economic instability of neighboring countries and its negative impact on the domestic economy (National Security Strategy, 2020) as one of the threats, Poland has chosen a course towards a more closed economy (Tymoshenko, 2020). This minimizes the negative impact of a negative trade balance on the development of the national economy;

- increasing trends in exports of digital services. Thus, the introduction of "packages of measures" to provide assistance to legal entities and individuals has increased the need for accounting, legal aid and IT services. According to experts, the digital services market now generates almost a third of Poland's budget revenues (Tsikhy, 2020). During the coronavirus crisis, this segment of services in Poland shows further growth.

It can be generally argued that thanks to modern digital technologies, Poland has become the European center for the provision of telecommunication and information services in the EU, which are ordered from different countries of 
Europe and the world. Therefore, this positive experience of digitalization and informatization of society is the most appropriate for implementa- tion in Ukraine in order to increase budget security at the current stage of the post-pandemic crisis.

\section{CONCLUSION}

In general, the formation of an effective model of budget security management and ensuring the consistency of budget and tax legislation in integration with effective measures to support the socio-economic environment and adaptation of Polish instruments to support the national economy of Ukraine are the key to stabilizing socio-economic development and overcoming existing post-pandemic crisis. In 2020, the government should take unprecedented measures to redirect existing resources to support SMEs, health care and social support. This may result in the need to abandon existing fiscal policy objectives or temporarily suspend fiscal policy. However, a well-balanced fiscal policy based on effective strategic planning of the level of budget security, taking into account projected changes, will provide an opportunity to put public finances on a solid foundation and will allow adapting to extreme macroeconomic uncertainty.

\section{AUTHOR CONTRIBUTIONS}

Conceptualization: Victoria Strilets, Olha Prokopenko, Volodymyr Orlov.

Data curation: Volodymyr Orlov.

Formal analysis: Olha Prokopenko.

Investigation: Victoria Strilets.

Methodology: Victoria Strilets, Olha Prokopenko, Volodymyr Orlov.

Project administration: Victoria Strilets, Olha Prokopenko, Volodymyr Orlov.

Resources: Victoria Strilets, Olha Prokopenko, Volodymyr Orlov.

Validation: Victoria Strilets, Olha Prokopenko, Volodymyr Orlov.

Visualization: Victoria Strilets, Olha Prokopenko, Volodymyr Orlov.

Writing - original draft: Victoria Strilets, Olha Prokopenko, Volodymyr Orlov.

Writing - review \& editing: Victoria Strilets, Olha Prokopenko, Volodymyr Orlov.

\section{REFERENCES}

1. Cabinet of Ministers of Ukraine. (2018). Osnovni napriamy biudzhetnoi polityky na 2019-2021 roky [On Priority Directions of Budgetary Policy for 2019-2021. Order dated April 18, 2018, No. 315-r. (in Ukrainian). Retrieved from https://zakon.rada.gov. ua/laws/show/315-2018\%D1\%80\#Text

2. Chugunov, I., Makohon, V., \& Markuts, Y. (2019). Budgetary policy of the emerging countries in conditions of institutional transformations. Problems and Perspectives in Management, 17(4), 252-261. http://dx.doi. org/10.21511/ppm.17(4).2019.21

3. Chugunov, I., Makohon, V., Vatulov, A., \& Markuts, Y. (2020).
General government revenue in the system of fiscal regulation. Investment Management and Financial Innovations, 17(1), 134142. http://dx.doi.org/10.21511/ imfi.17(1).2020.12

4. European Commission (EC). (2011). Public finances in EMU. Retrieved from https://ec.europa. eu/economy_finance/publications/ european_economy/2011/pdf/ee2011-3_en.pdf

5. European Commission (EC). (2020). European Economic Forecast (Institutional Paper No. 132). Retrieved from https://ec.europa. eu/info/sites/info/files/economyfinance/ip132_en.pdf

6. Frolov, S. M., Kozmenko, O V., \& Boiko. A. O. (2015).
Upravlinnia finansovoiu bezpekoiu ekonomichnykh subiektiv [Financial security management of economic entities] (332 p.). (In Ukrainian).

7. Hotlib, I. H. (2019). Analiz biudzhetnoi polityky Ukrainy [Analysis of budget policy of Ukraine]. Naukovyi visnyk Uzhhorodskoho natsionalnoho universytetu - Scientific Bulletin of Uzhhorod National University, 24(1), 111-116. (In Ukrainian).

8. Jarkinbayev, Z. A., \& Kosherbayeva, A. (2018). Problems in evaluating accuracy and consistency of macroeconomic forecasts. Problems and Perspectives in Management, 16(2), 102-112. http://dx.doi. org/10.21511/ppm.16(2).2018.10 
9. Kudriashov, V. P. (2012). Stability of state's finance. Journal of Economy of Ukraine, 10, 54-67. Retrieved from http://www. irbis-nbuv.gov.ua/cgi-bin/irbis_nbuv/cgiirbis_64.exe?C21 $\mathrm{COM}=2 \& \mathrm{I} 21 \mathrm{DBN}=\mathrm{UJRN} \& \mathrm{P} 2$ $1 \mathrm{DBN}=\mathrm{UJRN} \& I M A G E \_F I L E$ DOWNLOAD=1\&Image_file_ name $=$ PDF/EkUk_2012_10_6.pdf

10. Kulytskyi, S. (2020). Problemy rozvytku ekonomiky Ukrainy, obumovleni pandemiieiu koronavirusu COVID-19 u sviti, ta poshuk shliakhiv yikh rozviazannia [Problems of economic development of Ukraine caused by the COVID-19 pandemic in the world, and finding ways to solve them]. Kraina: podii, fakty, komentari - Country: events, facts, comments, 9, 47-53. (In Ukrainian). Retrieved from http://nbuviap. gov.ua/index.php?option=com_co ntent\&view $=$ article\&id $=4856$ :e konomichnij-vimir-zakhodivborotbi-z-epidemieyu-covid-19-vukrajini \&catid $=8 \&$ Itemid $=350$

11. Kyshakevych, B. Yu. (2012). Creation of the financial security system in Ukraine under the light of globalization. Naukovyi visnyk NLTU Ukrainy - Scientific bulletin of UNFU of Ukraine, 22(7), 202207. (In Ukrainian). Retrieved from https://cyberleninka.ru/ article/n/formuvannya-sistemifinansovoyi-bezpeki-ukrayini-vumovah-globalizatsiyi/viewer

12. Lyulyov, O. (2017). Impact of state finance on macroeconomic stability of Ukraine. Public and Municipal Finance, 6(3), 1722. http://dx.doi.org/10.21511/ pmf.06(3).2017.02

13. Makarchuk, I. M., Vynohradnia, V. M., \& Malyshko, V. V. (2017). Otsinka ta shliakhy zabezpechennia biudzhetnoi bezpeky Ukrainy [Assessment and ways to ensure the budget security of Ukraine]. Ekonomika i suspilstvo - Economy and society, 12, 560-565. (In Ukrainian).

14. Ministry for Development of Economy, Trade and Agriculture of Ukraine. (2013). Pro zatverdzhennia Metodychnykh rekomendatsii shchodo rozrakhunku rivnia ekonomichnoi bezpeky Ukrainy [On the Approval of Methodological Recommendations for Calculating the Level of Economic Security of Ukraine]. (In Ukrainian). Retrieved from https://zakon.rada.gov.ua/rada/ show/v1277731-13\#Text

15. Ministry for Development of Economy, Trade and Agriculture of Ukraine. (2020). Konsensusprohnoz "Vplyv COVID-19 na ekonomiku i suspilstvo - postpandemichnyi rozvytok" [Consensus forecast "Impact of COVID-19 on the economy and society - post-pandemic development"]. (In Ukrainian). Retrieved from https://www.me.gov. ua/Documents/Detail?lang=ukUA\&id=63a21de0-ad56-4954bb93-1ec3d335802e\&title=Vipusk vplivCovid19-NaEkonomikuISusp ilstvoPostpandemichniiRozvitokKonsensusprognoz-lipen2020-

16. National Security Strategy of the Republic of Poland. (2020). Retrieved from https://www.bbn.gov. pl/ftp/dokumenty/National_Security_Strategy_of_the_Republic_of_Poland_2020.pdf

17. NISS. (2017). Biudzhetna bezpeka Ukrainy $v$ koordynatakh hibrydnykh zahroz finansovii systemi: Analitychna zapyska Natsionalnoho instytutu stratehichnykh doslidzhen [Budget security of Ukraine in the coordinates of hybrid threats to the financial system: Analytical note of the National Institute for Strategic Studies]. (In Ukrainian). Retrieved from https://niss.gov. ua/doslidzhennya/ekonomika/ byudzhetna-bezpeka-ukraini-vkoordinatakh-gibridnikh-zagrozfinansoviy

18. NISS. (2020). Shchodo podolannia kryzovykh tendentsii promyslovosti Ukrainy, vyklykanykh pandemiieiu COVID-19: analitychne doslidzhennia Natsionalnoho instytutu stratehichnykh doslidzhen [On overcoming the crisis trends of Ukrainian industry caused by the COVID-19 pandemic: an analytical study by the National Institute for Strategic Studies]. (In Ukrainian). Retrieved from https://niss.gov. ua/doslidzhennya/ekonomika/ schodo-zakhodiv-z-podolannyakrizovikh-tendenciy-u-promislovosti-ukraini
19. Pedchenko, N. S., \& Strilets, V. Yu (2014). Biudzhetnyi potentsial rehionu: otsinka ta perspektyvy rozvytku [Budget potential of the region: assessment and development prospects] (220 p.). (In Ukrainian). Retrieved from https://core.ac.uk/ download/pdf/300237579.pdf

20. Sytnyk, N. S., \& Subytska, D. Ia. (2018). Biudzhetna bezpeka Ukrainy: zahrozy ta napriamy yii zmitsnennia [Budget security of Ukraine: threats and directions for its strengthening]. Prychornomorski ekonomichni studii Black Sea Economic Studies, 34, 167-171. (In Ukrainian). Retrieved from http://bses.in.ua/journals/2018/34_2018/37.pdf

21. Tsikhy, H. (2020). Zvit analitychnoho tsentru Polityka Insight - Report of the Analytical Center Polityka Insight. (In Ukrainian). Retrieved from https://www.politykainsight.pl/new/events

22. Tymoshenko, O. V. (2020). Dosvid Yevropeiskykh krain shchodo formuvannia ta zabezpechennia finansovo-ekonomichnoi bezpeky derzhavy [The experience of European countries in the formation and provision of financial and economic security of the state]. Ekonomika ta derzhava - Economy and state, 4, 52-57.

23. Zakharchenko, V., \& Zakharchenko, S. (2016). Fiscal state as a factor international Ukraine competitiveness and regions: evaluation and improving ways. Problems and Prospects of Economics and Management, 4(8), 159167. Retrieved from http://nbuv. gov.ua/UJRN/ppeu_2016_4_23

24. Zveruk, L. A., \& Bilyk, O. H. (2017). Biudzhetna bezpeka yak vazhlyvyi priorytet rozvytku biudzhetnoi systemy Ukrainy [Budget security as an important priority for the development of the budget system of Ukraine]. Mizhnarodnyi Naukovyi Zhurnal "Internauka" - International Scientific Journal "Interscience", 2(2), 35-39. (In Ukrainian). Retrieved from http://nbuv.gov.ua/UJRN/ mnjie_2017_2_8 